\title{
Geography, Memory and Non-Representational Geographies
}

\author{
Owain Jones* \\ $x x x x x x x x x x x$ \\ (4)
}

\section{Abstract}

I discuss the presence of memory within geography, particularly in relation to the interweaving non-representational/peformative/affective 'turns'. Memory seems under-considered in these nonrepresentational geographies (nrgs) which focus on the affective performativities of the present and the richness and creative potentials therein. As memory is a fundamental aspect of becoming, the roles it plays in the peformative moment need to be considered. Richness, potential and creativity emerges not simply from the moment per se, but from the legacies of the past carried into the present, not least through memory which underpins imagination, creativity and (productive) affective exchange. Emerging work on geography and memory does show some 'non-representational' traits and thus there is a potential for bringing this kind of work more fully into nrg. This is set in wider contexts of geographical approaches to memory, and the notion of ecologies of memories which form of interlinkages between individuals, various social collectives, materialities, texts, and past/present/future timespaces.

\section{Introduction}

The present is clearly burdened with all our temporalities. (Dodgshon 2008, 300)

Maybe we don't, can't, choose what to remember. Maybe we can't control what blunders and tumbles into our days. (Griffiths 2008, 169)

In his article Steps to an Ecology of Place Thrift (1999), drawing upon Derrida (1991), talks of memories as a 'world of cinders' and as a 'register of experience that cannot be escaped' (315). Cinders is surely the wrong term - the cold, dead, inert incombustible remains after fire. Better is embers, for they retain a trace of fire - of life - and if disturbed, or fanned by a breath of air, can burst back into renewed life.

Also, are memories wished away? 'That which cannot be escaped'? In Thrift's (2008) non-representational theory (nrt), memory seems underplayed in relation to its close cousins, imagination, emotion, affect. This relative neglect of memory is prevalent elsewhere in nrg. Pile's (2009) comprehensive consideration of affective/emotional geographies and nrg, includes lengthy ruminations on (un)consciousness, thought, language and so on, but memory barely features. Similarly in other key expressions of nrg (Anderson and Harrison 2010; Harrison 2007, 2008; McCormack 2007), 'affect', 'emotion', 'body', 'self are key themes, whereas memory is at best a ghostly presence (for exceptions, see Anderson 2004; Lorimer 2006). Memory makes us what we are, and, along with emotion/affect, forms the interrelating foundational processes of our ongoing lives (Damasio 1999), and is inextricably linked to imagination/creativity (Greenfield 1997). We are conglomerations of past everyday experiences, including their spatial textures and affective registers. Memory should not be seen as a burden of the past, rather it is fundamental to 
becoming, and a key wellspring of agency, practice/habit, creativity and imagination, and thus of the potential of the performative moment that so interests nrg.

Nrg focuses upon practice/performativity/affect as it unfolds - the present moment of practice (pmp) - because that is where life happens. Not only are pmps complex timespace 'events' where meanings and values are constructed, they are rich with ontological, political and ethical potentials. My concern is that nrg can creep towards a form of 'presentism' - a reification of the pmp in intellectual, political and ethical terms - due to its relative neglect of the trajectories of the past-into-present which are always in place through various interconnecting ecological, corporeal, material, cultural, economic and memorial flows.

Dodgshon (2008, 303) discusses how non-representational geographies (nrgs) have focused on 'the geographies on the moment' and the 'present of the now' (citing May and Thrift 2001, 37), and how Deleuzean inspired scholars such as Dewsbury have sought to see the present moment as the zone of creative proliferations of possibilities, and as the key 'space' for addressing the practicing of life. The 'presentism' that this risks is to load all the source of the richness and potentiality of the pmp onto the very fact that it is the frontier, or the living space of becoming, and to devalue the fact that 'each present carry syntheses of all the past within itself at various levels of contraction' (Dodgshon 2008, 304). This then is not about the values of pmps (or nrgs) but rather about the source of 3 that potential and the extent to which the present moment is seen as a 'pure' event.

As will be briefly reviewed, geography has a rich legacy of engaging with memory. Certain elements of this could be usefully drawn into the nrg milieu to ensure that this fundamental aspect of life is more fully accounted for. In return, this lends weight to those who are developing accounts of geography-memory which do draw nrg type approaches, either explicitly or implicitly, into their work, with an emphasis on performativity, affect, practice and potentiality as they address how always-memory-rich-life is practiced.

There is much to be considered within the interrelationships between individual memory (that which is practiced within the neural networks of the individual) and what is variously called public, social, cultural or collective memory (that which is strung out between people, objects, texts, media and across timespace). As nrg is very much about practice/process at the bodily level, memory systems at the level of the organism must be vital. I challenge nrg to more fully engage with memory's role in the affective, performative practices of everyday life, in ways which can address the complex ecologies of memory (and forgetting) which interlink through individual practicing bodies, texts, materialises, past/resent/future timespaces to make the present time deep/complex rather than flat/pure.

\section{Memory Processes and Their Centrality to Life}

Memory is the 'cornerstone of the mind' - 'it is more than a mere function of the brain, as it encapsulates individuals' inner resources for interpreting [ the world around them' (Greenfield 1997, 146). At its most basic, memory is a process of encoding and storing records of experience which can be retrieved, or which re-emerge, in subsequent practice. This sequence occurs both voluntarily and involuntarily, but importantly, is overwhelmingly the latter, and also highly intricate.

Firstly 'memory' covers not one process but a whole set of complex interrelating processes (Foster 2009). There are many contesting models of this complexity, but also recognition of at least three main types of interacting memory - short term, long term 
and sensory. These in turn are divided into sub-systems, for example, long term memory entails procedural memory (skills) and declarative memory (facts - somatic and episodic) (Foster 2009).

Secondly, the interplay between the conscious and unconscious within thought/memory is a vital question in terms of becoming (Schacter 1989; Tulving 1993) and there are questions about what status retrieved memory has in the mind's eye. Does it stop being memory and become thought? We generally don't and can't control memory in either the laying down of information or in its retrieval/re-emergence. Memories well up out of the depths of the unconscious and/or work away as dis/enabling background. They are not static information, but are reworked in the light of current practice.

New meanings change the past. It is reinterpreted, [] it is reorganized, repopulated. It becomes filled with new actions, new intentions, new events that caused us to be as we are. I have to discuss not only making up people but making up ourselves by reworking our memories. (Hacking 1998, 6)

Thus memory not only informs/enables the performative moment, there is an creative exchange between the two.

Thirdly memory is intimately entwined with many other functions; with that of the body (Weiss 1999), emotions and the senses (Jones 2005), and creativity. 'For the poet or 5 the artist, "the past" is much what "nature" is [-] the raw stuff which he (sic) uses' (Thorpe 2009, 1). Thus, the potentialities of the present rest upon creative forces flowing through time and not simply on the indeterminacy of the present moment.

Memory renders our relationships with others, timespace, information and materiality complex, multidimensional and non-linear. Memories are spatially and temporally complex, or even weird. Dreams are vital-to-life forms of memory which are extraordinary travels in timespaced events. Another way of appreciating the centrality of memory to life-going-on is to read clinical accounts of those who are unfortunate enough to have damaged memory functions and the profound dysfunctionality this brings (Brok 2003).

\section{Geography, Memory, Place and Landscape}

Geography has engaged with memory as a central aspect everyday life practice (Atkinson 2007; Dodgshon 2008; Johnson 2005; Legg 2004, 2007) focusing on a range of spatial registers/processes, such as national identity (Gillis 1996; Pred 2004; Schama 1995; ToliaKelly 2010); its memorialisation and contestation (Legg 2005; Till 2003, 2008); cities (Crang and Travlou 2001); historical landscapes (Della Dora 2008); tourist landscapes 6 (DeLyser 2003); place and memorialisation (Hoskins 2007; Mitchell 2003).

Given the violent (post)colonial experiences of modern history, and associated conflicts, slaughters, displacements/migrations, it is not surprising that work has focused on key events and their fallout, such as the holocaust, and the breakup of the British Empire (Blunt 2005). The geopolitics of war (Curti 2008) and their accompanying geomemories are painful, fraught and ongoing. Sidaway (2009) usefully summarises the recent literature on memory and conflict;

There is an enormous literature investigating and exemplifying [these] and other aspects of memory, conflict, and public space. See Carl Grundy-Warr and Sidaway (1996) and Sidaway and Mayell (2007) for pointers on [] political geography, memorials, and erasure. On the wider relationships between memory, performance, monuments, political transformation, and public space, see the introduction to the collection by Daniel Walkowitz and Lisa Maya Knauer 
(2004). For studies of the cultural intersections between war, memory, and history in the UK and elsewhere in Europe, see Richard Lebow et al. (2006).

Added to this litany of troubled/displaced/remembered/forgotten lives are instances of environmental/climate change driven losses and displacement (e.g. Cannavò 2008).

Memory is centrally important to ideas of place (Creswell 2004) and landscape (Wylie 2007). Both are based upon some notion of knowable (remembered) physical space which is distinguished from that around it by having a unique configuration - city, district, park, house, vista, a place where something special happened (first kiss, death of a loved one). Notions of being-in-place are powerful, even fundamental to everyday life (Casey 1993). Within this memory is key as it is one means by which people are in place/landscape. Recently some geographers have been keen to portray places/landscapes as much as temporal processes as they are spatial entities (Amin and Thrift 2002; Massey and Thrift 2003) with distinctive patternings forming out of intersecting passages of all manner of human and non-human traffic. If anything, memory becomes more critical still in weave such places together.

\section{FROM COLLECTIVE MEMORIES TO ECOLOGIES OF MEMORIES}

From the pioneering work of Halbwachs (1992) and within much of the above, there has been a focus on public, social, shared, collective memories, as these are such powerful life/space/place shaping forces.

Whether one refers to 'collective memory', 'social memory', 'public memory', 'historical memory', 'popular memory' or 'cultural memory', most would agree [with Edward Said] that many 'people now look to this refashioned memory, especially in its collective forms, to give themselves a coherent identity, a national narrative, a place in the world. (Hoelscher and Alderman 2004, 348-349)

The recent overview of memory in geography (Johnson and Pratt 2009) refers overwhelmingly to various forms of collective memories particularly those revolving around national identities.

While an overly sharp distinction between collective memories and individual memories is untenable, we do need to attend more fully to the more specific, intimate, private memories of individuals and families. It is possibly the focus on collective/cultural memories which has confined memory to the margins of nrg. For interests in memory to 'fit' within nrgs more intimate, relational, performative bio-cultural approaches are needed. Each of us bears freights of memory bound up with the domestic spaces and collectives we grew up in (Dillon 2006). These shape us and our practices most profoundly. There are ecologies of memory (Tolia-Kelly 2010) that exist between the public and the private, between larger histories and those of families and individuals, between memory functions, material, texts, images and senses.

\section{Memory and the Non-Representational Turn}

As already set out much is made of the pmp in nrg as pioneered by Thrift (2004a,b, 2008) and embellished by others (Anderson and Harrison 2010; Dewsbury et al. 2002; Harrison 2007; Lorimer 2005; McCormack 2007; Pile 2009). The present is where life is actually lived - the ever-moving front of becoming with all its material, embodied, relational, affective, performative richness and possibility. 
This is a world between potential and determination, between what has happened and what could, a world captured in the tension of its present tense of becoming, a not yet enacted moment where we meet and greet ourselves in the affect that inspires action. (Dewsbury et al. 2002, 439)

It is here that nrg can stray towards a kind of 'presentism' where the event is taken as pure - in isolation from temporal trajectories. Life in (extreme) present tense. This comes from interests in practice and perfomativity, and all the import of their actual doing, and from all the possibilities of the event - which might always go differently - and flicker new ethics and politics into life. Once opened up to scrutiny, the pmp becomes a complex affective terrain. Thrift (2008) has highlighted the moment of 'raw life' (the small lag between initiation of action and consciousness of action) and all the political, ethical, disciplinary and even commercial import it has. But the richness and potential of the pmp comes from what flows into it from previous moments, materially, through the body, through memory of one kind or other.

Something of the discounting of individual memory is evident in recent highly influential (nrg-related) writings on landscape [Sebald 1998 (not a geographer but a striking writer on landscape); Wylie 2005, 2007, 2009]. These articles offer rich performative/phenomenological accounts of being-in-landscape, opening up embodied practices (walking, climbing, sitting, looking, engaging with the immediate materiality), (in some respects) the hidden histories and connectivities of the landscapes, and the conceptual milieu the walkers carry with them. What is striking is that the landscapes are not previously (habitually) known to the writers. They come as strangers. This does not devalue these accounts, the strangeness of landscape is key to the project as the moment of encounter is pure. But these works would have had to be markedly different if these were familiar places to the writers through their own memories - maybe as landscapes of childhood, or as walked with a lover in previous times. Most people live and work in landscapes familiar to them and thus their immersion in them is temporal and memorial as well as performative/embodied and spatial. As Williams (1985, 72) says

The landscape takes on a different quality if you are one of those who remember. The scenery is [ ] never separate from the history of the place, from the feeling for the lives that have been lived there.

Saramago $(2009,13)$ also stresses that when considering a landscape we are never just in 'the precise moment when the landscape lies in front of us' but are strung out in time through 'memory and modes'. For a reminder of how markedly places and walks can be shaped and shadowed by memories, see Sidaway (2009).

Memory is a key means by which the present is practiced. Calvin (1996) (drawing upon Gombrich) says that 'perception may be regarded primarily as a modification of [ ] anticipation' (33). So our dealings with(in) the present rest upon our always-at-work memories and stocks of experience to script our responses and actions. Hunter (1964, 14-15) puts it thus:

memory [ ] contains one common thread of meaning [ ] what the person does and experiences here and now is influenced by what he [sic] did and experienced at some time in his past. When we talk of [ ] memory we are [ ] drawing attention to relationships between past and present activities. These relationships arise out of a fundamental characteristic of human beings.

Some work does deal with memory at the more personal level, addressing how our spatial relations are not merely relations between current body and current space, but a 
hyper-complex entanglement of past/present spatial relations. In his exploration of an 'ecological-economic' experiment in reindeer herding in Scotland, Lorimer (2006) explores a number of 'registers of memory', these being photographic, textual, embodied, oral, human and non-human. And Lorimer $(2007,6)$ concludes, in a brief review of memory as cultural rhythm and cycle;

Evidently, memory functions by different modes, whether it is carefully orchestrated or floods over us, whether it is felt to inhabit commonplace actions, treasured sites or discarded goods.

Anderson (2004) talks of the moment when someone chooses to play a record out of their collection, stating, 'to play music incorporates the momentary performance of an intentional act of discretion' (6). This is clearly to an extent true, but I feel the degree of intentional discretion is open to question. Or rather, the relationship between conscious choice and all the unconscious processes which are framing and forming that choice are more murky and complex than we know and probably can know. Why do we choose what we choose? The choice rises up from the unconscious memory the workings of which are - at best - very obscure.

\section{Weird Timespaces (Memories of Geographies and Geographies of Memories)}

Thrift (2008, 118, citing Gell 1998, 222-223) does say that people are;

rather ill-defined constellations [ ] not confined to particular spatio-temporal coordinates, but consist of a spread of biographical events and memories of events, and a dispersed category of material objects, traces, and leavings.

So we don't just 'live in the moment' but in a progressing compendium of interacting lived moments. Memory 'fragments space' (Mels 2004) and time, and builds us from those reworked fragments.

This view does not deny the progression of physical time through which, say, bodies grow and age (think of dendrology). But it takes a Bergsonian-Deleuzian notion of duration in time in different ways by differing materials/beings. Pasts persist as virtual fields which may or may not fold into the present. Memory is a key form of such 'timespace travel', along with materiality and (sensed) embodiment. We are scattered in timespace through memory and other vectors. As Ingold says of 'taskscapes', they

have a temporal aspect. In the present [ ] they are experienced as a muscular engagement but [they] also involve retentions of the past, as experience and memory; and projections into the future, as hopes, aspirations. (cited in Pearson 2006, 219)

Bergson $(2004,170)$ points out that 'perception is never a mere contact of the mind with the object present; it is impregnated with memory-images which complete it as they interpret it'.

Damasio (1999) has stated that affective becoming does make us transient entities of the present moment, and yet, at the same time, we have an 'autobiographical self, 'a nontransient collection of unique facts and ways of being of systemised memory' (17). We are thus becoming creatures of spatial remains. Our spatial relationships of the moment are shaped by previous experiences. Memory (of one kind or another) is then a fundamental aspect of becoming, intimately entwined with space, affect, emotion, imagination and identity. Understanding the nature of time and the relationship between past, present and future is a daunting challenge that human knowledge has made little impact on thus 
far. But in dealing with how we live in timespace, memory is clearly central, but is consequences uncertain. 'Past and present might be concurrent or not, might stop and start with the erratic spasms of the mind, of memory' (Schwartz 2007, 14).

Geographical work is emerging which deals with memory at the more personal, individual level, trying to address how our spatial relations, our spatial lives are not merely present relations between body and current space, but a fantastically complex entanglement of self, past spatial relations and memory in current life. Work has begun to explore complex and fractured relationships between past, present, material traces and place (DeSilvey 2006; Lorimer 2006; Lorimer and MacDonald 2002; Tolia-Kelly 2004). This 8,9 shares interests with work that explores how memory is mediated through performance and art intervention (Bosco 2004; Pinder 2001; Till 2005), exploring how the self is a contingent practice, where outcomes result from collaboration between individuals, groups, objects all of which can occupy the past as much as the present and how there is an exchange between individual and collective memories (Papoulias 2003). There is a particular focus on the entanglements of materiality, memory, time, place and practice (DeSilvey 2007) which stresses the performative and affective, but which sees such processes as time deep. Edensor (2005) has considered the affective materiality of being amongst industrial ruins, and Pile (2005), Till (2005) have considered how ghosts, and 10 memories as ghosts, can haunt cities.

All this work does then explore ecologies of memory as an emergent contingent element of similarly practiced selves. These are then developing nrg type reflections on practices of self but stressing the embeddedness in time through materiality, body and memory, rather than embeddedness in present flat space. This chimes with nrg's focus on the practice and the performativity of the affected/affecting body. Collective memories are vital but in the end they are lived out in individualised contexts of everyday lives in bodies moving through timespace.

Cues for presenting the filigrees of memory/self/place/place/practice can also be found in literature, theatre and performance studies. Heddon (2008) explores a number of autobiographical performance based 'autotopographies' which delve into past-self-in-place. A key example is Pearson (2006) which explores memory and past life in landscape through a series of performances and what are geographical accounts of a personal history in home, family, locality and region. Dillon (2006) charts the entangled memories, emotions and domestic spatialities of a remembered family home after the death of a parent. Prosser (2005) offers an alternative account of how photographs interplay with memory, time and loss. King (2000) explores autobiographical texts (films, popular fictions, women's writing) to explore how self is constructed through narrative and memory. Madden, in the film My Winnipeg, magically recreates the entanglements of memories of growing up in a city and a family within that city. Benjamin (2006) similarly explores growing up in a city, and the domestic spaces of the home, in an account with stresses objects, spaces and memory, more than the conventional structure of chronological life events. Proust, in the monumental In Search of Lost Time, journeys into the remembered past (as lived/ living space) precipitated by unbidden memories. What is distinctive about these works is that they are attempts to grapple with the uniqueness of individual (geographic) memory and the complexities of revisiting other spaces and times which remain with(in) us as we live on.

Mantel (2003) suggests that there are many geological understandings of memory (e.g. layers - like strata). She says that for her, 'memory is like St. Augustine's spreading limitless room. Or a great plain, a steppe, where all the memories are laid side by side, at the same depth, like seeds under the soil' (25). I don't feel such static spatial metaphors are 
adequate for memory. Memory is formed of living labyrinthine entanglements of many virtual (living) landscapes in unconscious memory stores, which are dark (as in not illuminated by conscious recollection) and thus unmapped and unmappable, but which are subject to the fluidity of emotional/affective convection currents (and more violent disturbances) as we live on and they might re-emerge in relation to current practice. The spatio-temporal weirdness of memory can be glimpsed in moments of reverie (Bachelard 1960), in flashes of involuntary memory which twist space-time (Game 1991, 2001), and in certain episodes of madness where people become overwhelmed by, and lost within, contortions of memory (Philo 2006).

Movement through chronological time and Euclidean space is scrambled with earliest memories becoming new memories once they are called into consciousness and refreshed and rescripted in relation to the present. Memories are living landscapes seen obliquely and from an always moving viewpoint of on-going-life. So I suggest memories are always in parallax, sliding over each other. Distant memories can seem to stand still, like a far-off hill seen from a moving train, making a backdrop to whatever the closer foreground has to show as it rushes by. But, of course, it is the perceiver who is moving through the moment as the near past and more distant past make an animated landscape.

\section{Conclusions}

Non-representational/emotional/affective approaches grew out of dissatisfaction with representational approaches because they drove too big a gap between the object of study and the process of study and because they missed not only the bulk of everyday life in practice, but also its richness, its key registers which are critical to politics, ethics, culture and economy. Here, I call for memory to be drawn more fully into these approaches as a counter to their tendency to presentism. The present is full of possibilities but those spring from the trajectories moving into the present as well as from the openness of the moment. Some of these trajectories will be sadness, damage, injustice and other burdens; others will be skill, happiness, joy, hope, love - our sum experience of spatial life which is always present in the present through memory.

Memory is a matter of ethics (Margalit 2004) formed both through collective memories which address, or otherwise, sufferings and injustices, and how we live with each other and each others' past lives. Geography can help open up the tracings of the spatial remains that make us. It can help trace out the legacies of the past we carry through memory as we practice the present and enter the future. Such tracings are not to tie us to any fixed past. They are, or can be, a creative (therapeutic) process of affective mapping.

The affective map is not a stable representational of a more or less unchanging landscape; it is a map less in the sense that it establishes a territory than it is about providing a feeling or orientation and facilitating mobility. [It suggests] something essentially revisable; when it works, it is a technology for the representation to oneself of one's own historically conditioned and changing affective life. (Flatley 2008, 7)

Opening up the implications of memory in individuals and groups (e.g. families) presents profound challenges in conceptual and methodological terms. It is often said that the greatest unknown lands for science to explore are now that of the brain and questions of consciousness in relation to emotion, affect and memory. The non-representational social sciences have their role to play in this, and exploring the implications of memory within them seems to me a demanding and exciting challenge. 


\section{Acknowledgement}

Huge thanks to the editor and two referees whose comments transformed this paper.

\section{Short Biography}

Xxxxxxx.

\section{Note}

* Correspondence address: Owain Jones, CCRI, Oxstalls Lane, Longlevens, Gloucester GL50 2RH, UK. E-mail: 19 owain.jones@uwe.ac.uk.

\section{References}

Amin, A. and Thrift, N. (2002). Cities: reimagining the urban. Cambridge: Polity.

Anderson, B. (2004). Recorded music and practices of remembering. Social and Cultural Geography 5 (1), pp. 1-19.

Anderson, B. and Harrison, P. (2010). Taking-place. Non representational theories and geography. London: Ashgate.

Atkinson, D. (2007). Kitsch geographies and the everyday spaces of social memory. Environment and Planning A 39 (3), pp. 521-540.

Bachelard, G. (1960). The poetics of reverie. Childhood language, and the cosmos. Boston: Beacon Press.

Benjamin, W. (2006). Berlin childhood around 1900. Cambridge, MA: Belknap Press.

Bergson, H. (2004). Matter and memory. New York: Dover Publications.

Blunt, A. (2005). Domicile and diaspora: Anglo-Indian women and the spatial politics of home. Oxford: Blackwell.

Bosco, F. (2004). Human rights politics and scaled performances of memory: conflicts among the Madres de Plaza de Mayo in Argentina. Social and Cultural Geography 5 (3), pp. 381-402.

Brok, P. (2003). Into the silent land. London: Atlantic Books.

Calvin, W. H. (1996). How brains think. London: Weidenfield and Nicolson.

Cannavò, P. (2008). In the wake of Katrina: climate change and the coming crisis of displacement. In: Vanderheiden, Steven J. and Barry, J. (eds) Political theory and global climate change. Cambridge: The MIT Press.

Casey, E. (1993). Getting back into place: towards an renewed understanding of the place-world. Bloomington: Indiana University Press.

Crang, M. and Travlou, P. S. (2001). The city and topologies of memory. Environment and Planning D, Society \& Space 19, pp. 161-177.

Creswell, T. (2004). Place. A short introduction. Oxford: Blackwell Publishing.

Curti, G. H. (2008). From a wall of bodies to a body of walls: politics of affect, politics of memory, politics of war. Emotion, Space and Society 1 (2), pp. 106-118.

Damasio, A. (1999). The feeling of what happens. Body and emotion in the making of consciousness. London: William Heinemann.

Della Dora, V. (2008). Mountains and memory: embodied visions of ancient peaks in the nineteenth-century Aegean. Transactions of the Institute of British Geographers 33 (2), pp. 217-232.

DeLyser, D. (2003). Ramona memories: fiction, tourist practices, and placing the past in Southern California. Annals of the Association of American Geographers 93 (4), pp. 886-908.

Derrida, J. (1991). Cinders. Lincoln, NE: University of Nebraska Press.

DeSilvey, C. (2006). Observed decay: telling stories with mutable things. Journal of Material Culture 11 (3), pp. 318 338.

DeSilvey, C. (2007). Salvage memory: constellating material histories on a hardscrabble homestead. Cultural Geographies 14, pp. 401-424.

Dewsbury, J. D., Harrison, P., Rose, M. and Wylie, J. (2002). Enacting geographies. Geoforum 33, pp. 437-440.

Dillon, B. (2006). In the dark room. A journey in memory. London: Penguin Books.

Dodgshon, R. A. (2008). In what way is the world really flat: debates over geographies of the moment. Environment and Planning: D Society and Space 26 (2), pp. 300-314.

Edensor, T. (2005). The ghosts of industrial ruins: ordering and disordering memory in excessive space. Environment and Planning D: Society and Space 23, pp. 829-849.

Flatley, J. (2008). Affective mapping: melancholia and the politics of modernism. Cambridge, MA: Harvard University Press.

Foster, J. K. (2009). Memory: a very short introduction. Oxford: Oxford University Press.

Game, A. (1991). Undoing the social: towards a destructive sociology. Milton Keynes: Open University Press. 
Game, A. (2001). Belonging: experience in sacred time and space. In: May, J. and Thrift, N. (eds) Times space: geographies of rhythm. London: Routledge.

Gell, A. (1998). Art and agency. Oxford: Blackwell.

Gillis, J. R. (1996). Commemorations: the politics of national identity. Princeton: Princeton University Press.

Greenfield, S. (1997). The human brain: a guided tour. London: Weidenfield and Nicolson.

Griffiths, N. (2008). In Netherley, Granta 102. The New Nature Writing.

Grundy-Warr, C. and Sidaway, J. D. (1996). Editorial: political geographies of silence and erasure. Political Geography 25, pp. 479-481.

Hacking, I. (1998). Re-writing the soul, multiple personality and the sciences of memory. Princeton: Princeton University Press.

Halbwachs, M. (1992). On collective memory. Chicago, IL: The University of Chicago Press.

Harrison, P. (2007). 'How shall I say it...?': relating the nonrelational. Environment and Planning A 39 (3), pp. 590608.

Harrison, P. (2008). Corporeal remains: vulnerability, proximity, and living on after the end of the world. Environment and Planning A 40, pp. 423-445.

Heddon, D. (2008). Autobiography and performance. Houndmills: Palgrave Macmillan.

Hoelscher, S. and Alderman, D. H. (2004). Memory and place: geographies of a critical relationship. Social \& Cultural Geography 5 (3), pp. 347-355.

Hoskins, G. C. (2007). Materializing memory at Angel Island immigration station. Environment and Planning A 39 (2), pp. 437-455.

Hunter, I. M. L. (1964). Memory. Harmondsworth: Penguin Books.

Johnson, N. C. (2005). Locating memory: tracing the trajectories of remembrance. Historical Geography 33, pp. 165179.

Johnson, N. C. and Pratt, G. (2009). Memory. In: Gregory, D., Johnston, R., Pratt, G., Watts, M. and Whatmore, S. J. (eds) The dictionary of human geography. 5th ed. Chichester: Wiley-Blackwell, pp. 453-455.

Jones, O. (2005). An emotional ecology of memory, self and landscape. In: Davidson, J., Bondi, L. and Smith, M. (eds) Emotional geographies. Oxford: Ashgate, pp. 205-218.

King, N. (2000). Memory, narrative, identity: remembering the self. Edinburgh: Edinburgh University Press.

Lebow, N., Kansteiner, W. and Fogu, C. (eds) (2006). The politics of memory in postwar Europe. Durham: Duke University Press.

Legg, S. (2004). Memory and nostalgia. Cultural Geographies 11 (1), pp. 99-107.

Legg, S. (2005). Contesting and surviving memory: space, nation, and nostalgia in Les Lieux de Memoire. Environment and Planning D: Society \& Space 23 (4), pp. 481-504.

Legg, S. (2007). Reviewing geographies of memory/forgetting. Environment and Planning A 39 (2), pp. $456-466$.

Lorimer, H. (2005). Cultural geography: the busyness of being 'more than representational'. Progress in Human Geography 29 (1), pp. 83-94.

Lorimer, H. (2006). Herding memories of humans and animals. Environment and Planning D: Society and Space 24 (4), pp. 497-518.

Lorimer, H. (2007). Cultural geography: worldly shapes, differently arranged. Progress in Human Geography 31 (1), pp. $1-12$.

Lorimer, H. and MacDonald, F. (2002). Rescue archaeology, Taransay, Scotland. Cultural Geographies 9, pp. 95103.

Mantel, H. (2003). Giving up the ghost. A memoir. London: Fourth Estate.

Margalit, A. (2004). The ethics of memory. Cambridge, MA: Harvard University Press.

Massey, D. and Thrift, N. (2003). The passion of place. In: Johnston, R. and Williams, M. (eds) A century of British geography. British Academy Centenary Monographs. Oxford, UK: Oxford University Press/British Academy, pp. 275-299.

May, J. and Thrift, N. (2001). Introduction. Timespace: geographies of rhythm. London: Routledge, pp. 1-46.

McCormack, D. P. (2007). Molecular affects in human geographies. Environment and Planning A 39, pp. $359-377$.

Mels, T. (2004). Lineages of geographies of rhythms. In: Mels, T. (ed.) Reanimating places: a geography of rhythm. Oxford: Ashgate.

Mitchell, K. (2003). Monuments, memorials, and the politics of memory. Urban Geography 24, pp. 442-459.

Papoulias, C. (2003). From the agora to the junkyard: social memory and psychic materialities. In: Radstone, S. and Hodgking, K. (eds) Regimes of memory. London: Routledge, pp. 114-130.

Pearson, M. (2006). "In Comes I': performance, memory and landscape. Exeter: University of Exeter Press.

Philo, C. (2006). Madness, memory, time, and space: the eminent psychological physician and the unnamed artist patient. Environment and Planning D: Society and Space 24, pp. 891-917.

Pile, S. (2005). Real cities: modernity, space and the phantasmagorias of city life. London: Sage.

Pile, S. (2009). Emotions and affect in recent human geography. Transactions of the Institute of British Geographers NS 35 , pp. 5-20.

Pinder, D. (2001). Ghostly footsteps: voices, memories and walks in the city. Cultural Geographies 8, pp. 1-19. 
Pred, A. (2004). The past is not dead: facts, fictions, and enduring racial stereotypes. Minneapolis: University of Minnesota Press.

Prosser, J. (2005). Light in the dark room: photography and loss. Minneapolis: University of Minnesota Press.

Saramago, J. (2009). Small memories: a memoir. London: Harvill Secker.

Schacter, D. L. (1989). Memory. In: Posner, M. I. (ed.) Foundations of cognitive science. Cambridge, MA: MIT Press, pp. $683-725$.

Schama, S. (1995). Landscape and memory. London: Fontana Press.

Schwartz, L. S. (2007). Introduction. In: Schwartz, L. S. (ed.) The emergence of memory: conversations with W. G. Sebald. New York: Seven Stories Press, pp. 9-22.

Sebald, W. G. (1998). The rings of Saturn. London: Harvill Press.

Sidaway, J. D. (2009). Shadows on the path: negotiating geopolitics on an urban section of Britain's South West Coast Path. Environment and Planning D: Society and Space, advance online publication.

Sidaway, J. D. and Mayell, P. (2007). Monumental geographies: re-situating the state. Cultural Geographies 14, pp. $148-155$.

Thorpe, A. (2009). In the land of Branwen and Pwyll. Guardian Newspaper, Review, 25 November, p. 7.

Thrift, N. (1999). Steps to an ecology of place. In: Massey, D., Sarre, P. and Allen, J. (eds) Human geography today. Oxford: Polity, pp. 295-352.

Thrift, N. (2004a). Summoning life. In: Cloke, P., Goodwin, M. and Crang, P. (eds) Envisioning human geography. London: Arnold, pp. 81-103.

Thrift, N. (2004b). Intensities of feeling: towards a spatial politics of affect. Geografiska Annaler 86 (B), pp. 57-78.

Thrift, N. (2008). Non-representational theory: space/politics/affect. London: Routledge.

Till, K. (2003). Places of memory. In: Agnew, J., Mitchell, K. and Tuathail, G. O. (eds) A companion to political geography. Oxford: Blackwell, pp. 289-301.

Till, K. (2005). The New Berlin: memory, politics, place. Minneapolis: University of Minnesota Press.

Till, K. (2008). Artistic and activist memory-work: approaching place-based practice. Memory Studies 1, pp. 95-109.

Tolia-Kelly, D. (2004). Locating processes of identification: studying the precipitates of re-memory through artefacts in the British Asian home. Transactions of the Institute of British Geographers 29, pp. 314-329.

Tolia-Kelly, D. (2010). Landscape, race and memory. Material ecologies of citizenship. Oxford: Oxford University Press.

Tulving, E. (1993). Varieties of consciousness and levels of awareness in memory. In: Baddeley, A. and Weiskrantz, L. (eds) Attention: selection, awareness, and control. A tribute to Donald Broadbent. London: Oxford University Press, pp. 283-299.

Walkowitz, D. J. and Knauer, L. M. (eds) (2004). Memory and the impact of political transformation in public space. Durham: Duke University Press.

Weiss, G. (1999). Body images: embodiment as intercorporeality. New York: Routledge.

Williams, R. (1985). The country and the city. London: The Hogarth Press.

Wylie, J. (2005). A single day's walking: narrating self and landscape on the South West Coast Path. Transactions of the Institute of British Geographers New Series 30, pp. 234-247.

Wylie, J. (2007). Landscape. London: Routledge.

Wylie, J. (2009). Landscape, absence and the geographies of love. Transactions of the Institute of British Geographers 34, pp. 275-289. 


\section{Author Query Form}

Journal: GEC3

Article: $\quad 459$

Dear Author,

During the copy-editing of your paper, the following queries arose. Please respond to these by marking up your proofs with the necessary changes/additions. Please write your answers on the query sheet if there is insufficient space on the page proofs. Please write clearly and follow the conventions shown on the attached corrections sheet. If returning the proof by fax do not write too close to the paper's edge. Please remember that illegible mark-ups may delay publication.

Many thanks for your assistance.

\begin{tabular}{|c|c|c|}
\hline Query reference & Query & Remarks \\
\hline Q1 & $\begin{array}{l}\text { AUTHOR: A running head short } \\
\text { title was not supplied; please check if } \\
\text { this one is suitable and, if not, please } \\
\text { supply a short title of up to } 40 \text { char- } \\
\text { acters that can be used instead. }\end{array}$ & \\
\hline Q2 & $\begin{array}{l}\text { AUTHOR: Please provide affiliation } \\
\text { for 'Jones'. }\end{array}$ & \\
\hline Q3 & $\begin{array}{l}\text { AUTHOR: Dodgson } 2008 \text { has been } \\
\text { changed to Dodgshon } 2008 \text { so that } \\
\text { this citation matches the Reference } \\
\text { List. Please confirm that this is cor- } \\
\text { rect. }\end{array}$ & \\
\hline $\mathrm{Q}^{4}$ & $\begin{array}{l}\text { AUTHOR: Please note that instances } \\
\text { of 'ibid' in your paper have been } \\
\text { replaced by the respective reference. } \\
\text { Please check if the replaced refer- } \\
\text { ences are correct. }\end{array}$ & \\
\hline Q5 & $\begin{array}{l}\text { AUTHOR: Jones } 2003 \text { has been } \\
\text { changed to Jones } 2005 \text { so that this } \\
\text { citation matches the Reference List. } \\
\text { Please confirm that this is correct. }\end{array}$ & \\
\hline Q6 & $\begin{array}{l}\text { AUTHOR: Crang and Travlou } 2004 \\
\text { has been changed to Crang and } \\
\text { Travlou } 2001 \text { so that this citation } \\
\text { matches the Reference List. Please } \\
\text { confirm that this is correct. }\end{array}$ & \\
\hline
\end{tabular}




\begin{tabular}{|c|c|}
\hline Q7 & $\begin{array}{l}\text { AUTHOR: Grundy-Warr and Sid- } \\
\text { away (2006) has been changed to } \\
\text { Grundy-Warr and Sidaway (1996) so } \\
\text { that this citation matches the Refer- } \\
\text { ence List. Please confirm that this is } \\
\text { correct. }\end{array}$ \\
\hline Q8 & $\begin{array}{l}\text { AUTHOR: Tolia-Kelley } 2004 \text { has } \\
\text { been changed to Tolia-Kelly } 2004 \text { so } \\
\text { that this citation matches the Refer- } \\
\text { ence List. Please confirm that this is } \\
\text { correct. }\end{array}$ \\
\hline Q9 & $\begin{array}{l}\text { AUTHOR: Lorimer and McDonald } \\
2002 \text { has been changed to Lorimer } \\
\text { and MacDonald } 2002 \text { so that this } \\
\text { citation matches the Reference List. } \\
\text { Please confirm that this is correct. }\end{array}$ \\
\hline Q10 & $\begin{array}{l}\text { AUTHOR: Pyle (2005) has been } \\
\text { changed to Pile }(2005) \text { so that this } \\
\text { citation matches the Reference List. } \\
\text { Please confirm that this is correct. }\end{array}$ \\
\hline Q11 & $\begin{array}{l}\text { AUTHOR: Please provide short } \\
\text { biography for this paper. }\end{array}$ \\
\hline Q12 & $\begin{array}{l}\text { AUTHOR: Please provide the page } \\
\text { range for reference Cannavò (2008). }\end{array}$ \\
\hline Q13 & $\begin{array}{l}\text { AUTHOR: Please provide the page } \\
\text { range for reference Game (2001). }\end{array}$ \\
\hline Q14 & $\begin{array}{l}\text { AUTHOR: Please check and also } \\
\text { provide missing details for reference } \\
\text { Griffiths (2008). }\end{array}$ \\
\hline Q15 & $\begin{array}{l}\text { AUTHOR: Please check the article } \\
\text { title in reference Hoskins (2007). }\end{array}$ \\
\hline Q16 & $\begin{array}{l}\text { AUTHOR: Please provide the editor } \\
\text { name(s) for reference May and Thrift } \\
\text { (2001). }\end{array}$ \\
\hline Q17 & $\begin{array}{l}\text { AUTHOR: Please provide the page } \\
\text { range for reference Mels (2004). }\end{array}$ \\
\hline Q18 & $\begin{array}{l}\text { AUTHOR: If it is published in print, } \\
\text { please provide the volume number, } \\
\text { page range and doi number for refer- } \\
\text { ence Sidaway (2009). }\end{array}$ \\
\hline
\end{tabular}


Q19

AUTHOR: Please provide department or organisation name for corresponding author. 
Required software to e-Annotate PDFs: Adobe Acrobat Professional or Adobe Reader (version 8.0 or above). (Note that this document uses screenshots from Adobe Reader $\mathrm{X}$ )

The latest version of Acrobat Reader can be downloaded for free at:http://get.adobe.com/reader/

Once you have Acrobat Reader open on your computer, click on the Comment tab at the right of the toolbar:

닙

This will open up a panel down the right side of the document. The majority of tools you will use for annotating your proof will be in the Annotations section, pictured opposite. We've picked out some of these tools below:

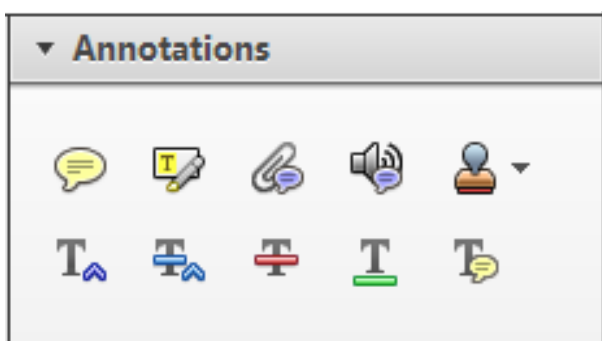

1. Replace (Ins) Tool - for replacing text.

\section{Strikes a line through text and opens up a text} box where replacement text can be entered.

\section{How to use it}

- Highlight a word or sentence.

- Click on the Replace (Ins) icon in the Annotations section.

- Type the replacement text into the blue box that appears.

Idard tramework for the analysis of $\mathrm{m}$ icy Nevertheless, it also led to exog،


aber of comp 08/06/2011 15:58:17 $\quad$ o

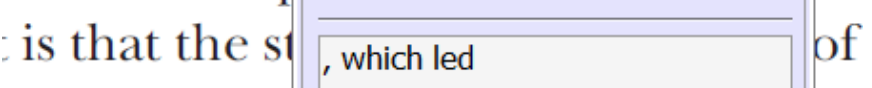
nain compo: be level, are exc nc

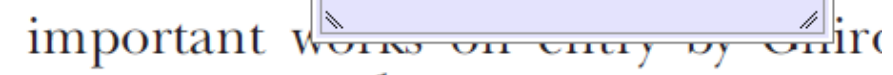
M heneforth) ${ }^{1}$ we anen the 'hlarl $\mathrm{h}$

3. Add note to text Tool - for highlighting a section to be changed to bold or italic.

Th Highlights text in yellow and opens up a text box where comments can be entered.

\section{How to use it}

- Highlight the relevant section of text.

- Click on the Add note to text icon in the Annotations section.

- Type instruction on what should be changed regarding the text into the yellow box that annears.

namic responses of mark ups ent with the VAR evidence

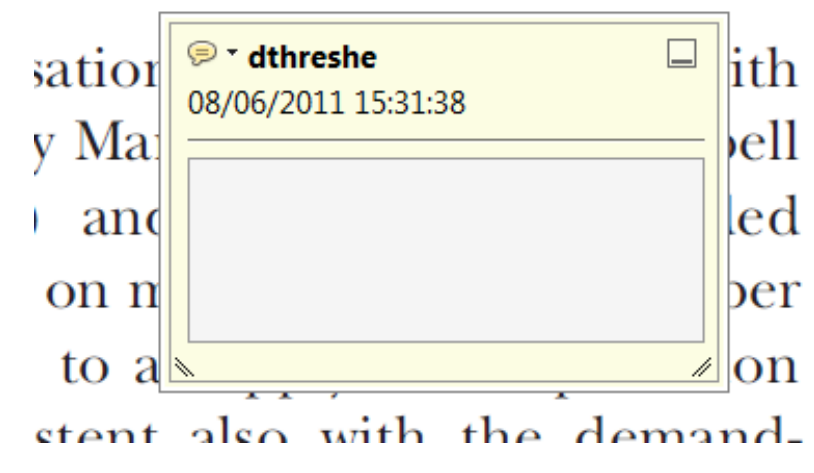

2. Strikethrough (Del) Tool - for deleting text.

Thikes a red line through text that is to be deleted.

\section{How to use it}

- Highlight a word or sentence.

- Click on the Strikethrough (Del) icon in the Annotations section.

there is no room for extra protits al c ups are zero and the number of ret) values are not determined by Blanchard and Kiyetaki (1987), rfect competition in general equilil ts of aggregate demand and supply lassical framework assuming monol eon an evorenois number of firms

\section{Add sticky note Tool - for making notes at} specific points in the text.

\section{Marks a point in the proof where a comment} needs to be highlighted.

\section{How to use it}

- Click on the Add sticky note icon in the Annotations section.

- Click at the point in the proof where the comment should be inserted.

- Type the comment into the yellow box that appears.

lallu allu suppiy silucks. Iviusl ul

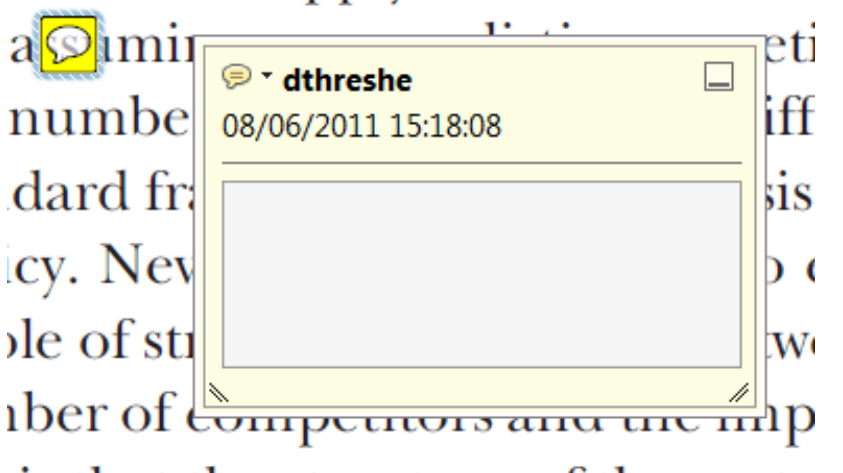

is that the structure of the secto 
5. Attach File Tool - for inserting large amounts of text or replacement figures.

Inserts an icon linking to the attached file in the appropriate pace in the text.

How to use it

- Click on the Attach File icon in the Annotations section.

- Click on the proof to where you'd like the attached file to be linked.

- Select the file to be attached from your computer or network.

- Select the colour and type of icon that will appear in the proof. Click OK.

E N D

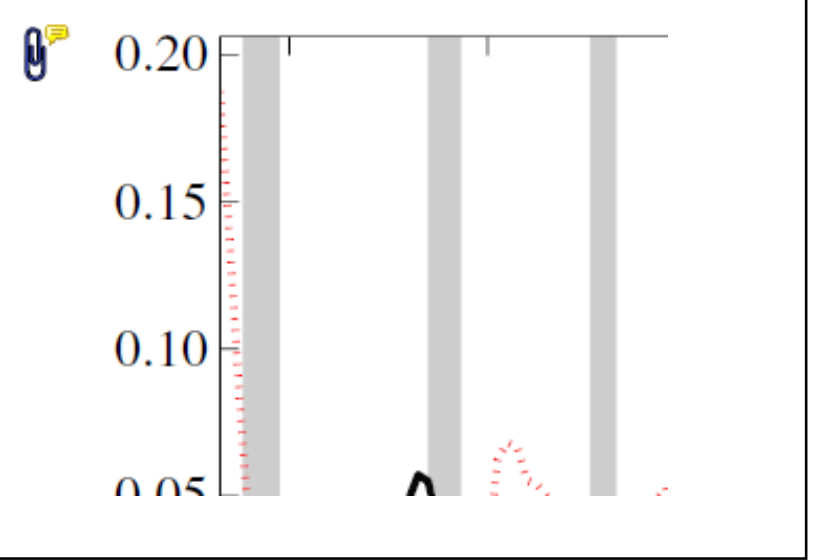

6. Add stamp Tool - for approving a proof if no corrections are required.

- Inserts a selected stamp onto an appropriate place in the proof

\section{How to use it}

- $\quad$ Click on the Add stamp icon in the Annotations section.

- Select the stamp you want to use. (The Approved stamp is usually available directly in the menu that appears).

- Click on the proof where you'd like the stamp to appear. (Where a proof is to be approved as it is, this would normally be on the first page).

of the Dusiness cycie, starting with the on perfect competition, constant ret

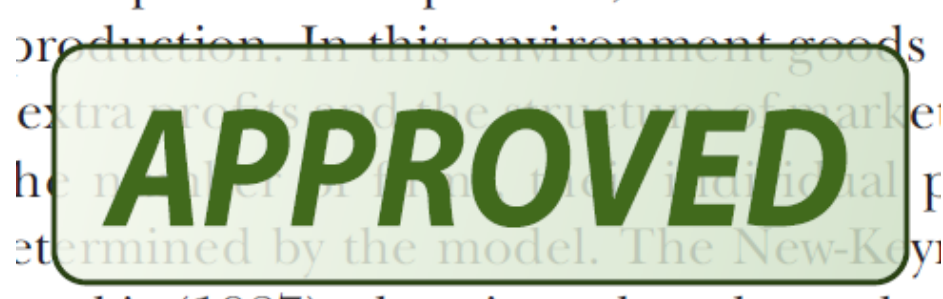

otaki (1987), has introduced produc general equilibrium models with nomin
- Drawing Markups

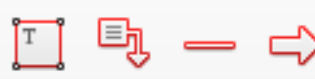

$0 \square \sqrt{6} D$

\section{How to use it}

- Click on one of the shapes in the Drawing Markups section.

- Click on the proof at the relevant point and draw the selected shape with the cursor.

- To add a comment to the drawn shape, move the cursor over the shape until an arrowhead appears.

- Double click on the shape and type any text in the red box that appears.
7. Drawing Markups Tools - for drawing shapes, lines and freeform annotations on proofs and commenting on these marks.

Allows shapes, lines and freeform annotations to be drawn on proofs and for comment to be made on these marks..

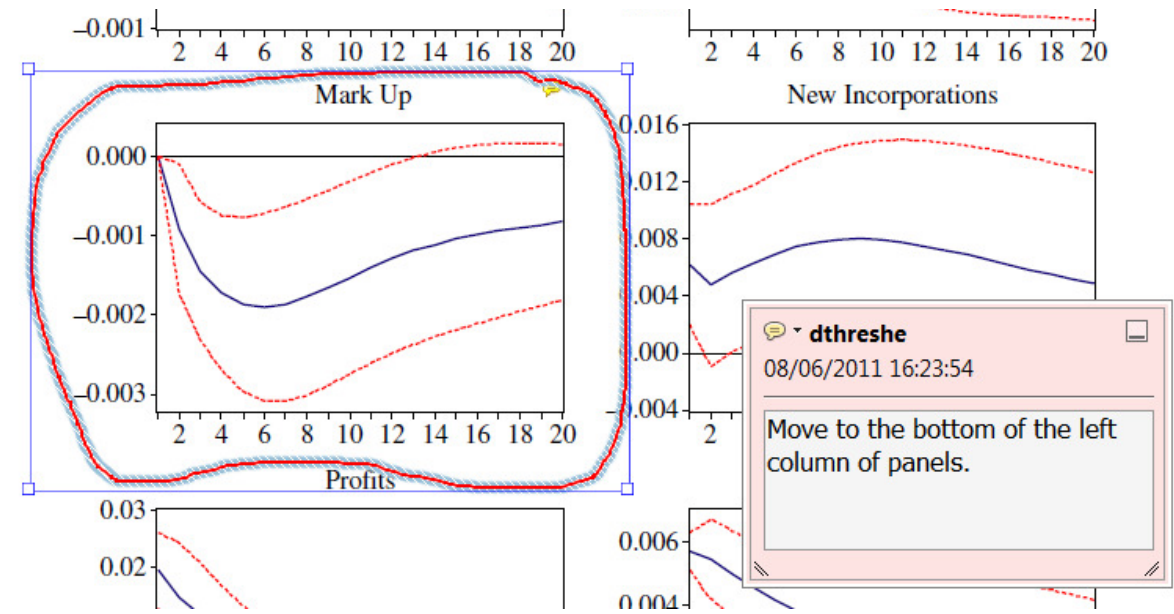

For further information on how to annotate proofs, click on the Help menu to reveal a list of further options:

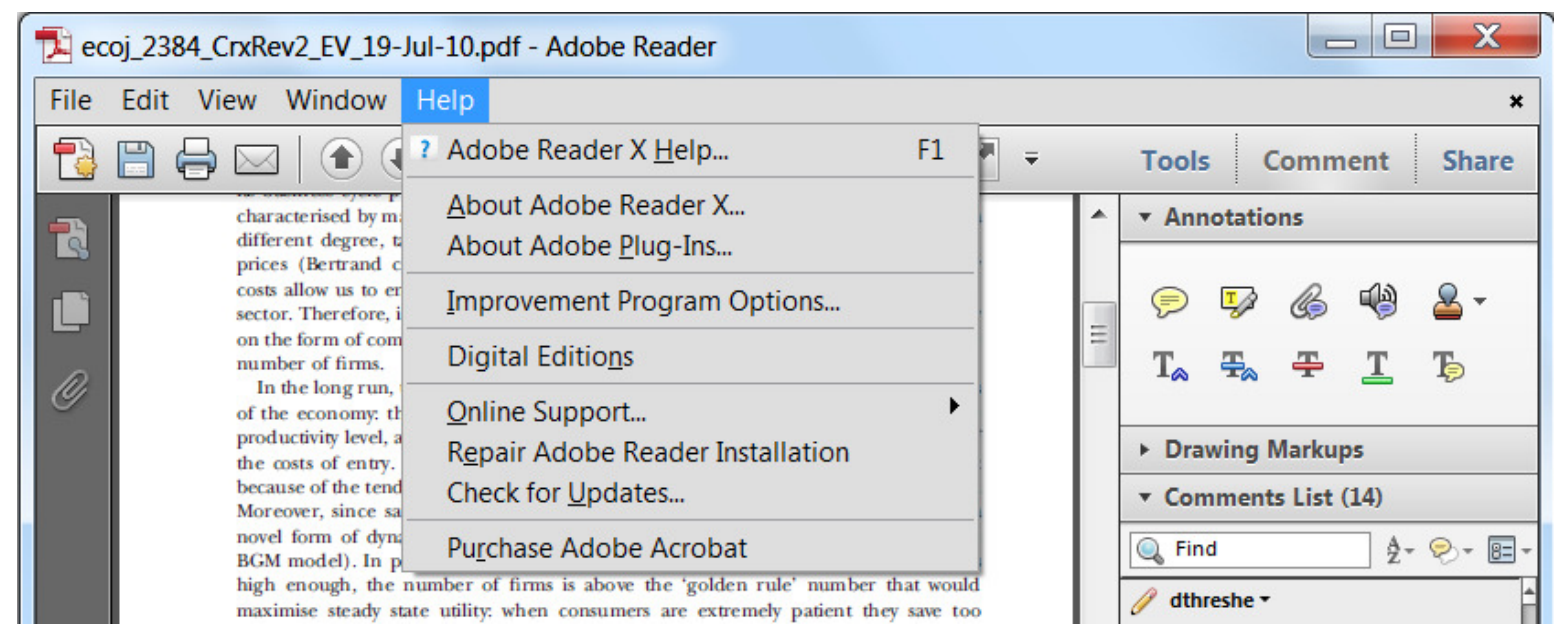

